\title{
Poly(rC)-Binding Protein 1
}

National Cancer Institute

\section{Source}

National Cancer Institute. Poly(rC)-Binding Protein 1. NCI Thesaurus. Code C95867.

Poly(rC)-binding protein 1 (356 aa, $\sim 37 \mathrm{kDa}$ ) is encoded by the human PCBP1 gene. This protein plays a role in the modulation of mRNA splicing. 